\title{
Mer evidens og mindre politikk, takk!
}

\author{
Det er sterke reaksjoner i de gynekologiske fagmiljøene på at grundig gjennomarbeidede og kunnskaps- \\ baserte kliniske retningslinjer settes til side ved et politisk pennestrøk.
}

Når slutter fag å være fag og blir politikk? Norsk gynekologisk forening har i mange år vært ledende i Den norske legeforenings kvalitetsarbeid. Veileder i fødselshjelp ble publisert i 1995 og blir jevnlig oppdatert med kunnskapsbaserte anbefalinger. Dette arbeidet, som har fått mye anerkjennelse både i Norge og i utlandet, er sentralt for klinisk praksis, ved vurderinger i pasientskadeerstatningsordningen og i rettssaker om mulig feilbehandling.

\section{Overtidig svangerskap}

I de to siste årene har det vært en uverdig mediedebatt om håndtering av overtidige svangerskap, ledet an av Folkehelseinstituttet (1-4). Folkehelseinstituttets innspill har gjort mange gravide unødig engstelige. I de gynekologiske fagmiljøene har diskusjonen vært konstruktiv, og det ble oppnådd en oppdatert konsensus, støttet av Helsedirektoratet, høsten 2010.

I mai 2011 oppnevnte så Helsedirektoratet helt overraskende en hurtigarbeidende gruppe som i løpet av 3-4 uker skulle komme med nye anbefalinger om overtidig svangerskap. Gruppens medlemmer ble oppnevnt i løpet av få dager, og Norsk gynekologisk forening klarte ikke å stille med ett medlem til tross for iherdige forsøk. Nye og avvikende forslag fra arbeidsgruppen ble umiddelbart distribuert og oppfattet som en instruks som skulle implementeres ved fødeavdelingene midt i fellesferien, uten forsøk på konsekvensanalyse med henblikk på kvalitet og kapasitet. De som ytret seg kritisk, ble nærmest satt i gapestokk i mediene.

På årsmøtet i Norsk gynekologisk forening i høst uttrykte generalforsamlingen, med stor deltakelse fra et samlet fagmiljø, seg svært kritisk til Helsedirektoratets behandling av denne saken, både hva gjelder prosess og konklusjon. Foreningen mener hastebehandlingen var unødig og ikke basert på nye norske data eller på ny vitenskapelig kunnskap. Veileder i fødselshjelp, som nylig er revidert etter en grundig prosess, gir fortsatt de beste kunnskapsbaserte anbefalinger.

\section{HPV-testing}

Våren 2011 fikk debatten om HPV-testing i det nasjonale screeningprogrammet mot livmorhalskreft stor oppmerksomhet. Norsk gynekologisk forening har i flere år påpekt uforsvarlig testbruk ved flere sykehus fordi testen som ble valgt, ikke har vært tilstrekkelig dokumentert for klinisk rutinebruk. Bruken var i strid med nasjonale anbefalinger, hadde et eksperimentelt preg, var uten godkjenning fra regional komité for medisinsk og helsefaglig forskningsetikk (REK) og uten samtykke fra kvinnene. Dette synet har etter hvert fått oppslutning fra både Kreftregisteret, Rådgivingsgruppen for masseundersøkelsen mot livmorhalskreft, Helsedirektoratets styringsgruppe og Helsedirektoratet selv i deres anbefaling til Helse- og omsorgsdepartementet om innskjerpede kvalitetskrav.

Likevel blir implementeringen overstyrt politisk etter intens lobbyvirksomhet og en beslutning i saken utsatt. Begrunnelsen var at man måtte vente på Kreftregisterets vurdering av prøveperioden 2005-08. Når det alt foreligger klare resultater fra en rekke randomiserte studier fra mange land, som viser at sensitiviteten av testen er for lav, er det vanskelig å forstå at norske resultater bør være avgjørende. Kunnskapsmessig blir det som å tillegge en sammenlikning mellom ukontrollerte pasientserier altfor stor betydning når studier med betydelig sterkere evidens allerede er publisert.

\section{Overstyring}

Faglig diskusjon er viktig, men debatten bør styres av faglige argumenter. Anbefalinger og retningslinjer bør være kunnskapsbasert. De nye anbefalingene fra Helsedirektoratet om håndtering av overtidig svangerskap blir av mange i fagmiljøet oppfattet som et pålegg om å endre rutiner. Flere avdelinger innførte de nye anbefalingene i sommer og rapporterer om betydelig økt arbeidsbelastning og en opplevelse av å bruke arbeidskraft og tid på unødige intervensjoner. Oppmerksomheten flyttes vekk fra omsorg og overvåking av fødende med større behov. De nye anbefalingene vil ved mange avdelinger føre til behov for flere jordmødre og gynekologer og økte kostnader om ikke kvaliteten i tjenesten skal reduseres.

Risikoen for fosterdød i Norge er blant de laveste i verden (2-4). Norske data og kunnskapsbasert kunnskap gir ikke grunnlag for de anbefalinger Helsedirektoratet nå har kommet med. De nye anbefalingene har ikke potensial for å gi bedre resultater for overtidige svangerskap. Det er derimot en klar risiko for uheldige konsekvenser, bl.a. fordi sikkerheten ved unødig mange induksjoner ikke er klarlagt.

Det er uakseptabelt at norske politiske myndigheter overstyrer faglige retningslinjer som er grundig behandlet i fagmiljøene og nylig revidert. De nye anbefalingene om overtidig svangerskap bør trekkes tilbake. Et fornuftig arbeidsklima og en rasjonell arbeidsform må gjenopprettes mellom de gynekologiske fagmiljøene og helsemyndig- hetene. Hvis ikke vil dugnadsånden i kvalitetssikringsarbeidet forsvinne og den faglige entusiasmen forvitre. Avmakten styrkes når samvittighetsfullt arbeid lett settes til side av politiske pennestrøk.

\section{Pål Øian}

pal.oian@unn.no

Kvinneklinikken

Universitetssykehuset Nord-Norge

Ole-Erik Iversen

Haukeland universitetssykehus

Knut Hordnes

Hospitalet Betanien

Bergen

Bjørn Backe

St. Olavs hospital

Pål Øian (f. 1948) er spesialist i fødselshjelp og kvinnesykdommer og er avdelingsoverlege og professor ved Kvinneklinikken, Universitetssykehuset Nord-Norge/Universitetet i Tromsø. Redaktør av Veileder i fødselshjelp. Ingen oppgitte interessekonflikter.

Ole Erik Iversen (f. 1945) er overlege ved Kvinneklinikken, Haukeland universitetssykehus og professor ved Institutt. for klinisk medisin, Universitetet i Bergen. Medlem i Styringsgruppen for Masseunders $ø$ kelsen mot livmorhalskreft. Oppgitte interessekonflikter: Forfatteren har mottatt honorar for foredrag fra MSD, SPMSD og Bayer.

Knut Hordnes (f. 1959) er spesialist i fødselshjelp og kvinnesykdommer og overlege ved Hospitalet Betanien, Bergen. Nestleder av Norsk gynekologisk forening.

Ingen oppgitte interessekonflikter.

Bjørn Backe (f. 1947) er overlege ved Kvinneklinikken, St. Olavs hospital og professor ved Institutt for laboratoriemedisin barne- og kvinnesykdommer ved Norges teknisk-naturvitenskapelige universitet. Leder i Norsk gynekologisk forening.

Ingen oppgitte interessekonflikter.

Litteratur

1. Frøen JF. Hvor mange barn bør dø? Dagens Medi$\sin 14.12 .2009$

2. Backe B, Øian P, Augensen K. På kollisjonskurs med dagens viten. Dagens Medisin 13.1./2010.

3. Augensen K, Backe B, Øian P. Overtidige svangerskap. Tidsskr Nor Legeforen 2011; 131: 562

4. Haavaldsen C, Sarfraz A, Eskild A. Lav fosterdødsrisiko etter termin i Norge. Tidsskr Nor Legeforen 2010; 130: 2114. 